\title{
Apa itu Turun Peranakan
}

\author{
M. Rizkar Arev Sukarsa, Aditya Wibowo, Arieff Kustiandi \\ Departemen Obstetri dan Ginekologi Fakultas Kedokteran Universitas Padjadjaran/ \\ RSUP Dr. Hasan Sadikin Bandung \\ Korespondensi: M. Rizkar Arev Sukarsa, Email: dr.adityawibowo88@gmail.com
}

\begin{abstract}
Abstrak
Tujuan untuk mengetahui lebih dalam tentang turun peranakan atau prolaps alat genitalia dapat disamakan dengan suatu hernia, dimana suatu organ genitalia turun ke dalam vagina, bahkan mungkin keluar liang vagina. Hal ini karena kelemahan otot fasia dan ligamen penyokongnya. Kerusakan pada penyangga vagina dapat terjadi dalam satu lokasi saja (misalnya, dinding vagina anterior saja), tetapi lebih sering terjadi kombinasi. Metode merangkum daftar referensi terupdate sebagai bahan artikel yang dapat menjadi pedoman dan tatalaksana prolaps organ panggul. Hasil tidak semua prolaps alat genitalia membutuhkan terapi, karena banyak penderita tidak mempunyai keluhan, terutama stadium I dan kadang-kadang stadium II. Pada mereka yang mempunyai keluhan tentu perlu penanganan dengan tepat agar penderita merasa lebih baik. Prolaps uteri stadium II dan III dipilih vaginal histerektomi dan disertai dengan kolporafi anterior dan kolpoperineorafi, Hal ini terutama bila penderita sudah mengalami manaupose atau tidak memerlukan lagi organ reproduksi. Kesimpulan, walaupun tidak mengancam nyawa, akan tetapi prolapsus alat genitalia dapat menurunkan kualitas hidup wanita.
\end{abstract}

Kata kunci : Prolap alat genital, kualitas hidup wanita

\section{What is Prolapse}

\begin{abstract}
Purpose to find out more about descent or genital prolapse can be likened to a hernia, in which a genital organ descends into the vagina, possibly even out of the vaginal canal. This is due to weakness of the fascial muscles and ligaments that support them. Damage to the vaginal support can occur in one location only (eg, anterior vaginal wall only), but is more common in combination. Although it does not cause death, pelvic organ prolapse can reduce the quality of life for women. Method summarize an updated list of references as material for articles that can guide and treat pelvic organ prolapse. Result not all prolapse of the genitalia needed therapy, because many patients had no complaints, especially stage I and sometimes stage II. Those who have complaints, of course, need to be handled properly so that the sufferer feels better. Uterine prolapse stages II and III were chosen by vaginal hysterectomy and accompanied by anterior colporaphy and kolpoperineorafi, especially if the patient has menopause, or no longer needs reproductive organs. Conclusion, although not life threatening, genital prolapse can reduce a woman's quality of life.
\end{abstract}

Key word: Prolap genitalia, quality of life for women 


\section{Pendahuluan}

Turun peranakan atau prolaps alat genitalia dapat disamakan dengan suatu hernia, dimana suatu organ genitalia turun ke dalam vagina, bahkan mungkin keluar liang vagina. Hal ini karena kelemahan otot fasia dan ligamen penyokongnya. ${ }^{1}$ Kerusakan pada penyangga vagina dapat terjadi dalam satu lokasi saja (misalnya, dinding vagina anterior saja), tetapi lebih sering terjadi kombinasi. ${ }^{2}$ Prolaps alat genitalia dapat berupa prolapsus uteri dan prolaps vagina. Prolaps alat genitalia secara klinik lebih mudah diklasifikasikan berdasarkan lokasi anatomi dan mudah dipahami dimulai dari anterior (introitus vagina) kearah posterior (puncak vagina).

Tingkatan (derajat) prolapsusnya didasarkan atas posisi letaknya dari introitus vagina tersebut, yaitu derajat satu kalau masih di atas introitus vagina (dalam vagina), derajat dua bila organ yang turun tersebut telah mencapai introitus vagina, derajat tiga, kalau bagian yang turun tersebut telah keluar introitus vagina. Prolapsus alat genitalia tersebut dapat berupa (berbentuk) uretrokel, uretrovesika, vesikokel (sistokel), prolaps uteri, entrokel, dan rektokel. Sedangkan bila prolaps tersebut terjadi sesudah operasi histerektomi (abdominal atau vagina) disebut prolaps vaginal tumpul atau vagina vault prolapse. ${ }^{3,4}$

Women's Health Initiative (WHI) menunjukkan bahwa sekitar $40 \%$ wanita akan mengalami prolaps organ panggul pada tingkat tertentu selama hidup mereka. Studi intervensi bedah berbasis populasi melaporkan risiko untuk menjalani operasi karena prolaps yang bergejala adalah $11 \%$ hingga 19\%. Penelitian sebelumnya telah menunjukkan bahwa tingkat prolaps yang lebih rendah terlihat pada wanita AfrikaAmerika dibandingkan dengan wanita kaukasia. ${ }^{4}$ Dalam penelitiannya, Hendrix menyebutkan bahwa pasien dengan ras Afrika-Amerika memiliki risiko lebih rendah mengalami prolaps uteri, sistokel, dan rektokel, dibandingkan pasien dengan ras putih-Hispanic. Dibandingkan dengan semua jenis ras, pada wanita dengan ras Asia memiliki risiko lebih besar mengalami sistokel dan rektokel. ${ }^{5}$

Pada derajat ringan (stadium I) atau sedang (stadium II) mungkin tidak ada keluhan, dan biasanya keluhan baru ada atau dirasakan penderita setelah stadium III (lanjut). Perlu diketahui dan dipahami bahwa tidak semua prolaps alat genitalia memerlukan terapi dan bila diperlukan terapi dapat dilakukan secara konservatif atau operatif.

Oleh karena itu, pengetahuan tentang prolaps genitalia ini termasuk penatalaksanaannya sangatlah penting baik oleh masyarakat (penderita) apalagi oleh tenaga medik. ${ }^{3}$

Prolaps organ panggul merupakan kondisi yang umum terlihat pada wanita yang sudah mengalami penuaan. Penyebabnya dikarenakan banyak faktor yang akan mengakibatkan pelemahan pada jaringan ikat dan otot penyangga panggul serta kerusakan saraf. Pasien kemungkinan tidak merasakan adanya gejala, tapi ada juga gejala yang dirasakan terkait dengan saluran kemih bagian bawah, nyeri panggul, masalah buang air besar, inkontinensia tinja, nyeri punggung, dan dyspareunia. ${ }^{6}$

Walaupun tidak menyebabkan kematian tapi prolapse organ panggul dapat menurunkan kualitas hidup wanita. ${ }^{7}$ Pemeriksaan fisik meliputi perhatian yang cermat pada semua bagian vagina, termasuk kompartemen anterior, apikal, dan posterior, otot levator, dan kompleks sfingter ani. ${ }^{6}$

\section{Anatomi Dasar Panggul}

Dasar panggul terdiri dari diaphragma pelvis, diaphragma urogenital dan otot penutup genitalia eksterna. Diaphragma pelvis merupakan penutup bagian bawah 
rongga perut, terdiri dari otot levator ani, otot koksigeus dan fasia endopelvis. Otot levator ani terbagi dua yaitu pubokoksigeus dan iliokoksigeus. Otot pubokoksigeus terdiri dari otot pubourethralis yang mengelilingi urethra dan pubovaginalis yang mengelilingi vagina dan puborektalis yang mengelilingi rektum.

Otot pubokoksigeus ini dalam keadaan normal fungsinya adalah untuk menggantung dan menarik urethra, vagina, dan rektum ke arah pubis anterior. Otot iliokoksigeus membentang dari spina iskhiadika dan arkus tendineus yang menutupi otot obsturator internus, terus ke belakang dan berinsersi di pinggir lateral tulang koksigeus dan sakrum bagian bawah. Otot levator ani kanan dan kiri membentuk levator plate yang kuat sekali dan terbentang mulai dari titik penggabungnya di belakang hiatus levator ani dan terus ke belakang dan berinsersi pada tulang koksigeus, central perineal body, dan ligamen anokoksigeus. Rektum dan vagina lewat melalui hiatus ini. ${ }^{3}$

Di atas otot levator ani bersandar vagina bagian atas dan rektum, yang dalam keadaan normal berada pada posisi horisontal dan paralel dengan levator plate. Otot levator ani dalam keadaan normal berfungsi:

- Mengerutkan lumen rektum, vagina, urethra dengan cara menariknya kearah dinding tulang pubis sehingga organ pelvis tidak jatuh atau turun.

- Mengimbangkan tekanan intraabdominal dan tekanan atmosir, sehingga ligament-ligamen tidak perlu bekerja mempertahankan letak organ-organ pelvic diatasnya.

- Sebagai sandaran dari uterus, vagina bagian atas, rektum dan kandung kemih.

Otot levator ani mendapat persarafan ganda yaitu dari cabang langsung nervus Sakralis 2-4 dan dari nervus pudenda. Secara umum, saraf pudenda relatif tetap karena berada di belakang ligamentum sakrospinous dan di dalam kanal pudendal. Oleh karena itu, ini mungkin berisiko teregang selama perpindahan ke bawah dari dasar panggul saat melahirkan. ${ }^{8}$

Bagian atas vagina, servik dan uterus melekat pada dinding panggul melalui lembaran fasia endopelvis. Jaringan ini dikenal sebagai ligamentum kardinale dan ligamentum sakrouterina. Meskipun berbeda nama namun sebenarnya merupakan suatu kesatuan dan berfungsi mempertahankan fungsi uterus dan bagian atas vagina agar berada dalam posisinya diatas otot levator ani. $^{3}$

Bila otot levator ani rusak maka ligamen seperti kardinale, sakrouterina dan fasia akan mempunyai beban yang berat untuk mempertahankan organ-organ yang digantungnya, sebaliknya selama otot levator ani normal, ligamen dan fasia dalam keadaan istirahat atau tidak berfungsi banyak. ${ }^{3}$

\section{Fisiologi Dasar Panggul}

Tulang dan jaringan ikat adalah komponen struktural utama panggul. Jaringan ikat terdiri dari ligamen dan fasia. Elemen penting dari jaringan ikat adalah kolagen dan elastin, yang keduanya berubah selama kehamilan, persalinan, dan penuaan. Perubahan ini dapat melemahkan ligamen dan fasia, sehingga mempengaruhi integritas struktural dasar panggul. Ini dapat menyebabkan prolaps dan memengaruhi fungsi organ. Struktur jaringan ikat diklasifikasikan dalam tiga tingkatan yaitu: ${ }^{13}$

Tingkat 1: Ligamen uterosacral, fasia puboserviks.

Tingkat 2: Ligamen pubourethral, fasia rectovaginal.

Tingkat 3: Ligamentum uretra eksternal, membran perineum, badan perineum.

\section{Disfungsi Dasar Panggul}

Disfungsi dasar panggul merupakan masalah 


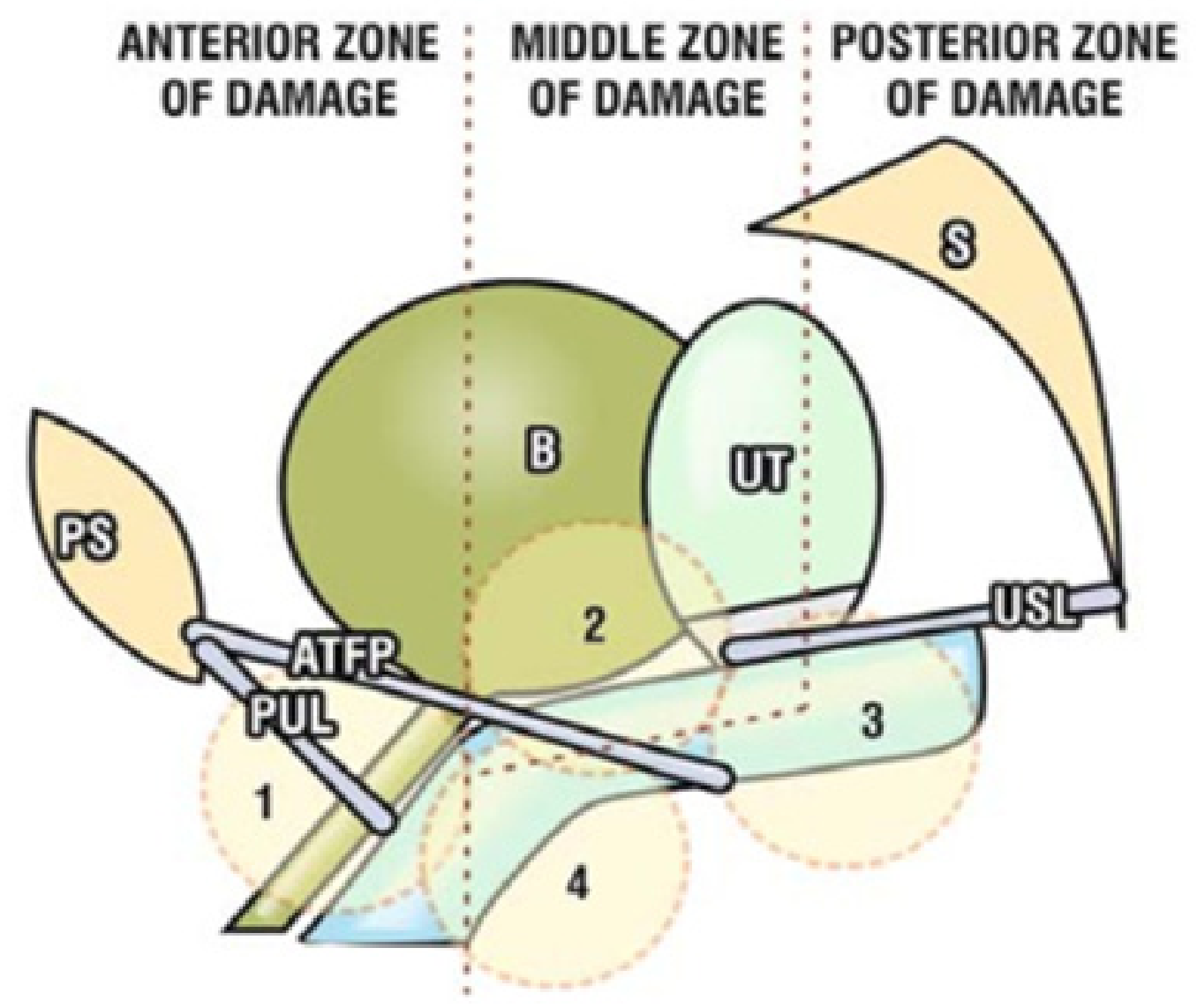

\section{Gambar 1 Kerusakan Zona-Zona Penyebab Disfungsi Dasar Panggul ${ }^{13}$}

yang luas. Inkontinensia urin merupakan keluhan yang paling umum terjadi. Selain itu, prolaps, inkontinensia fekal, dan nyeri panggul juga merupakan disfungsi dasar panggul yang sangat mempengaruhi sejumlah besar wanita. Disfungsi dasar panggul disebabkan oleh jaringan ikat yang rusak pada ligamen suspensori dan fasia yang terletak di tiga zona: anterior, tengah, dan posterior.

Zona anterior memanjang dari meatus uretra eksternal ke leher kandung kemih, dan berisi tiga struktur yang mungkin rusak: ligamentum pubourethral (PUL), suburethral hammock, dan ligamentum uretra eksternal (EUL). Zona tengah memanjang dari leher kandung kemih ke serviks atau bekas luka histerektomi. Ini berisi tiga struktur yang mungkin rusak: fasia pubocervical (PCF), arcus tendineus fasciae pelvis (ATFP), dan cincin serviks anterior. Zona posterior meluas dari bekas luka serviks atau histerektomi ke badan perineum. Ligamen uterosakral (USL), fasia rektovaginal (RVF) dan badan perineum (PB) adalah struktur zona posterior kunci yang mungkin rusak. Teori Integral menetapkan bahwa jaringan ikat yang rusak di ligamen suspensori atau fasia dapat menyebabkan gejala berikut: inkotinensia stres, dorongan berkemih, sering buang air kencing, nokturia, pengosongan kandung kemih yang abnormal, inkotinensia fekal, dan nyeri panggul. ${ }^{13}$

\section{Definisi \\ Definisi Disfungsi Dasar Panggul}

Disfungsi dasar panggul adalah suatu keadaan terganggunya fungsi dasar panggul. Disfungsi dasar panggul merupakan keluhan 
paling umum diraskan perempuan terutama setelah melahirkan. Persalinan vaginal menjadi faktor yang sangat berpengaruh terhadap terjadinya disfungsi dasar panggul yaitu sebanyak lebih dari $46 \%$ perempuan. $^{7}$

\section{Definisi Prolaps Organ Panggul (POP)}

Prolaps organ panggul adalah tonjolan atau penonjolan organ panggul dan dinding vagina ke dalam liang vagina atau keluar introitus vagina. ${ }^{6,14}$ Meskipun tidak berakibat pada kematian, tapi prolapse organ panggul dapat berdampak pada menurunnya kualitas hidup wanita. $^{7}$

\section{Definisi Sistokel}

Sistokel adalah turunnya kandung kemih dengan dinding vagina anterior. Sistokel biasanya terjadi ketika jaringan muskulokonektif puboserviks melemah atau terlepas dari titik penghubung lateral atau superior. ${ }^{6}$

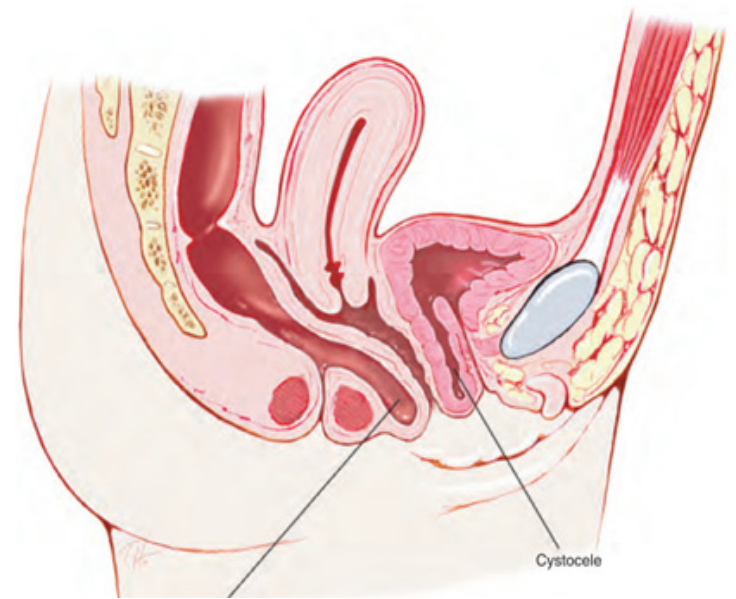

Gambar 2 Sistokel ${ }^{6}$

\section{Definisi Rektokel}

Rektokel adalah penonjolan rektum ke dalam lumen vagina akibat kelemahan pada dinding otot rektum dan jaringan muskulokonektif paravaginal, yang menahan rektum pada tempatnya di posterior. ${ }^{6}$

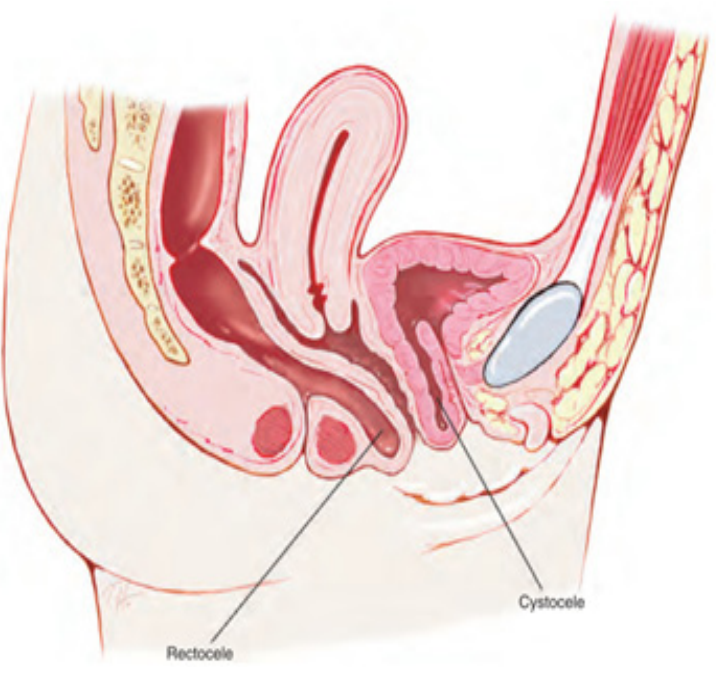

\section{Gambar 3 Rektokel ${ }^{6}$}

\section{Definisi Enterokel}

Enterokel merupakan satu-satunya hernia sejati di antara gangguan penyangga panggul. Enterokel ditandai dengan herniasi peritoneum dan usus halus. Sebagian besar enterokel terjadi ke bawah antara ligamen uterosakral dan rongga rektovaginal, tetapi dapat juga terjadi terutama di apikal, terutama apabila memiliki riwayat histerektomi sebelumnya. $^{6}$

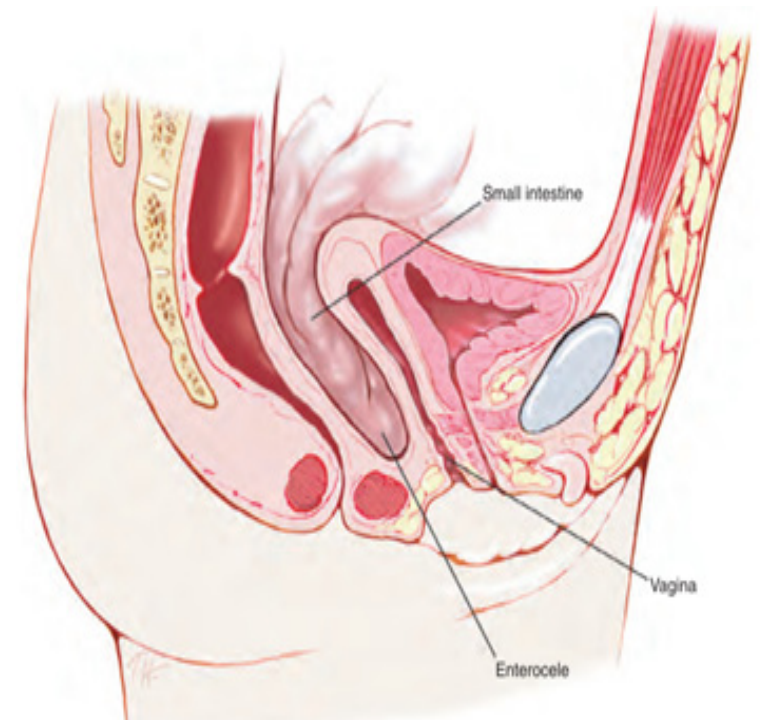

Gambar 4 Enterokel $^{6}$ 


\section{Definisi Prolaps Uteri}

Prolaps uterus umumnya disebabkan oleh penyangga apikal ligamentum kardinal atau uterosakral yang buruk, yang memungkinkan tonjolan ke bawah dari serviks dan uterus menuju introitus. ${ }^{6}$

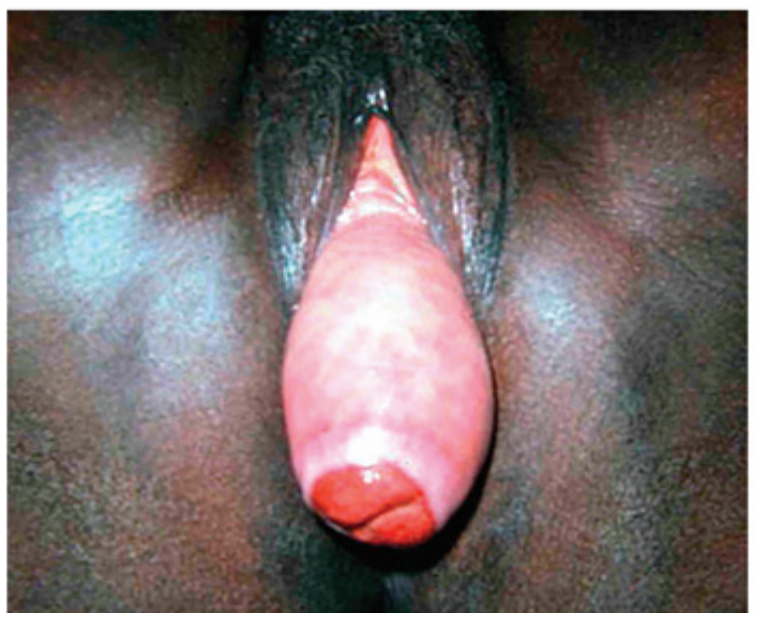

Gambar 5 Prolapsus Uteri ${ }^{6}$

\section{Definisi Prolaps Tumpul Vagina}

Prolaps tumpul vagina terjadi paling sering pada pasien yang pernah menjalani histerektomi. ${ }^{4}$ Prolaps tumpul vagina adalah turunnya vaginal cuff di bawah titik yaitu 2 $\mathrm{cm}$ lebih kecil dari total panjang vagina di atas bidang selaput dara. Ini terjadi ketika vagina bagian atas menonjol ke dalam atau di luar vagina. ${ }^{15}$

\section{Angka Kejadian}

Prolapsus alat genitalia yang sering ditemukan adalah urethrosistokel, sistokel, prolapsus uteri, dan rektokel. Urethrokel saja jarang terjadi, sedangkan entrokel lebih sering ditemukan terutama pada pasien pasca histerektomi dan diperkirakan 50\% dari wanita yang telah melahirkan akan menderita prolapsus genitalia, dan hampir $20 \%$ kasus ginekologi yang menjalani operasi adalah kasus prolapsus genitalia. Kasus prolapsus uterus ini akan meningkat jumlahnya karena usia harapan hidup wanita juga meningkat. ${ }^{1}$

Prolaps organ panggul (POP) adalah salah satu indikasi paling sering dari operasi ginekologi. Menurut penelitian oleh The Women's Health Initiative(WHI), kejadian POP di Amerika Serikat adalah 41\% wanita berusia 50-79 tahun dan prolapsus uteri menempati urutan ketiga $(14 \%$ pasien dengan POP). ${ }^{16}$ Prolaps organ panggul hampir ditemukan pada semua wanita yang telah melahirkan, tapi hanya $5-20 \%$ yang bergejala. ${ }^{14}$

Chang dan Sultana dalam studinya menyebutkan bahwa wanita Asia memiliki tingkat prolaps organ panggul yang lebih tinggi daripada wanita dalam kelompok ras lain yatu $67 \% .{ }^{17}$ Data mengenai angka kejadian prolapsus uteri di Indonesia belum banyak diketahui. ${ }^{1,18}$ Penelitian yang dilakukan di Jawa Barat yang melibatkan subjek penelitian yaitu pasien prolapsus uteri dan tanpa prolapsus uteri di Rumah Sakit Hasan Sadikin Bandung, RSUD Sumedang, RSUD Ujung Berung, dan RSUD Garut selama periode November-Desember 2008 didapatkan bahwa usia 50 tahun atau lebih memiliki risiko prolapsus uteri sebanyak 9 kali bila dibandingkan dengan usia kurang dari 50 tahun. Selain itu, dalam penelitian ini juga didapatkan bahwa kerapatan kolagen ligamentum sakrouterina pada pasien prolapsus uteri lebih rendah dibanding dengan pasien tanpa prolapseus uteri. ${ }^{18}$

Menurut laporan tahunan Bagian Obstetri dan Ginekologi RS Hasan Sadikin pada tahun 2007 didapatkan kejadian prolapsus uteri yaitu 30 kasus dan terdapat 13 kasus prolapse uteri yang dilakukan histerektomi vaginal., 18. Selain itu, di Poliklinik Ginekologi RSUD Dr. Soetomo dari tahun 2007 - 2011 , angka kejadian prolapsus uteri cukup tinggi dan merupakan kasus POP terbanyak yaitu 66,30\%. ${ }^{16}$ Diperkirakan selama 30 tahun ke depan, permintaan pengobatan POP akan meningkat $45 \%$, sejalan dengan peningkatan populasi wanita berusia di atas 50 tahun. ${ }^{6}$ 


\section{Etiologi}

Etiologi prolaps alat genitalia adalah kelemahan dasar panggul yang terdiri dari otot-otot fasia endopelvik dan ligamenligamen yang menyokong organ-organ genitalia tersebut. Kelemahan jaringan penyokong panggul, meliputi otot, ligamnet, dan fascia, berkontribusi terhadap terjadinya prolapsus uteri. Persalinan pervaginam merupakan penyebab paling signifikan terhadap terjadinya prolaps organ panggul. Hal ini dikarenakan posisi fetal vertex yang melalui vagina mengakibatkan peregangan pada otot levator ani dan saraf pudendal sehingga terjadi kerusakan permanen neuropati dan melemahnya otot. ${ }^{14,19}$

Seiring bertambahnya usia, kadar estrogen akan mengalami penurunan sehingga berkontribusi terhadap kehilangan kekuatan dan keelastisitasan jaringan panggul. Begitu pula ini terjadi pada kondisi ketika pasien menopause. Kadar kolagen yang rendah juga berkontribusi dalam terjadinya prolapsus uteri, seperti yang ditunjukkan pada pasien dengan sindrom Marfan dan sindrom Ehlers Danlos. ${ }^{14}$

Pasien yang memiliki riwayat operasi pada jaringan panggul, histerektomi, dan adanya kecacatan atau kerusakan kongenital turut berkontribusi dalam terjadinya prolaps organ panggul. ${ }^{19}$

\section{Patologi}

Tulang panggul berfungsi tempat melekatnya jaringan penunjang dan sebagai kerangka yang mengelilingi dan melindungi organ didalamnya. Fungsi penyokong visera panggul terutama berasal dari aktifitas otot dasar panggul bersama fasia dan ligamennya yang bekerjasama dalam menyokong visera panggul tetap berada dalam posisinya. ${ }^{9}$

Ada 3 mekanisme dasar yang menjelaskan bagaimana uterus dan vagina tetap berada pada posisinya, yaitu:
1. Fasia endopelvis menyokong uterus dan vagina dengan menempel pada dinding lateral pelvis

2. Otot levator ani berkontraksi menarik lumen sehingga membentuk lapisan penutup dimana organ pelvis ini dapat bersandar.

3. Bertindak sebagai katup penutup yang merupakan hasil kerja gabungan kedua struktur tadi. ${ }^{12}$

Tekanan yang terus-menerus yang dialami oleh ligamen dan fasia pada pelvis akibat fungsinya mempertahankan organ abdomen juga akan menyebabkan ligamen dan fasia menjadi kendor. Otot levator ani yang normal akan membuat hiatus genitalis tetap tertutup sehingga tidak terdapat regangan pada fasia endopelvis. Kerusakan pada otot dasar panggul akan menyebabkan ligamen dan fasia akan bekerja keras dalam menunjang beban yang suatu saat akan melampaui batas sehingga menimbulkan prolapsus. $^{12}$

Otot dasar panggul dapat melemah akibat trauma persalinan, neuropati pelvis, usia, operasi histerektomi, defisiensi hormon karena menopause, meningkatnya tekanan intraabdominal yang kronis atau akibat kelainan congenital yang menyebabkan levator ani akan kehilangan tonus istirahat dan tidakdapat berkontraksi dengan cepat dan kuat saat tekanan intraabdomen meningkat, juga faktor ras dan kelainan bawaan. ${ }^{12}$

Vagina bagian atas terbaring di atas rektum keduanya terletak horisontal pada levator plate (merupakan gabungan otot levator ani di bagian tengah). Vagina bagian tengah dipegang pada posisi horisontal oleh serabut parakolpikum yang merupakan lanjutan dari ligamentum kardinale dan ligamentum sakrouterina yang melekatkan pada bagian lateral dengan arkus tendineus dan fasia dari otot levator ani. ${ }^{11}$

\section{Faktor Risiko}


Penyebab secara umum prolapsus genitalis adalah partus yang terlampau sering, partus dengan penyulit / menggunakan alat dan juga dapat memperburuk prolapsus yang sudah ada.

\section{Usia}

Penelitian menunjukkan bahwasanya akan terjadi peningkatan prevalensi dan insidensi dari prolaps organ panggul seiring meningkatnya usia. Dalam sebuah penelitian yang dilakukan oleh Hendrik dkk, menemukan pada usia lanjut terdapat peningkatan risiko perkembangan prolaps uteri, rektokel, dan sistokel . Pada perempuan yang berusia 60-69 tahun memiliki oddsratio (OR) 1.16 kali lebih tinggi mengalami prolaps uteri dibandingkan dengan wanita yang berusia 50-59 tahun dan odds-ratio (OR) pada wanita berusia 70-79 tahun yaitu 1.36 kali lebih tinggi. Operasi POP pada pasien yang berusia kurang dari 30 tahun dan di atas 80 tahun jarang dilakukan. ${ }^{5}$

Shervil dalam studinya menyimpulkan bahwa usia merupakan faktor risiko utama yang memengaruhi derajat prolaps uteri yang dikarenakan melemahnya jaringan dasar panggul dan otot pada wanita yang telah lanjut usia. ${ }^{16}$

\section{Ras}

Operasi prolaps organ panggul pada pasien yang memiliki ras kulit putih lebih tinggi bila dibandingkan dengan pasien denga ras Afrika-Amerika. Dalam penelitiannya, Hendrix menyebutkan bahwa pasien dengan ras Afrika-Amerika risiko lebih rendah mengalami prolaps uteri, sistokel, dan rektokel, dibandingkan pasien dengan ras putih-Hispanic. Dibandingkan dengan semua jenis ras, pada wanita dengan ras Asia memiliki risiko lebih besar mengalami sistokel dan rektokel. ${ }^{5}$

\section{Paritas}

Menurut OxfordFamily Planning Association, paritas merupakan faktor risiko terkuat untuk terjadinya dan perkembangan dari prolaps organ panggul dengan relatiive Risk (RR) yaitu 10.85. Hendrix juga menemukan dalam studinya adanya hubungan antara meningkatnya paritas dengan peningkatan risiko prolaps uteri, sistokel, dan rektokel.

Dalam penelitian analisis multivariat Nygaard menemukan bahwa wanita yang melahirkan pervaginam memiliki risiko lebih tinggi mengalami prolaps organ paanggul dibandingkan dengan yang tidak melahirkan pervaginam. Sebagaimana penelitian Nygaard, penelitian case-control yang dilakukan oleh Moalli menyebutkan bahwa wanita yang melahirkan pervaginam mengalami peningkatan risiko operasi dasar panggul dibandingkan dengan melahirkan secara seksio sesaria. ${ }^{5}$

\section{Obesitas}

Hendrix dalam penelitiannya menyebutkan bahwa wanita dengan indeks masa tubuh $25-30 \mathrm{~kg} / \mathrm{m}^{2}$ mengalami risko peningkatan terjadinya prolaps uteri sebanyak $31 \%$, , rektokel sebanyak 38\%, dan sistokel sebanyak 39\%. Pada wanita obesitas dengan indeks masa tubuh lebih dari $30 \mathrm{~kg} / \mathrm{m}^{2}$ mengalami peningkatan terjadinya prolaps uteri sebanyak $40 \%$, rektokel sebanyak $75 \%$, dan sistokel sebanyak $57 \%{ }^{5}$

Wanita dengan lingkar pinggang $88 \mathrm{~cm}$ atau lebih memiliki peningkatan risiko $17 \%$ mengalami sistokel dan rektokel. Sebagai perbandingan, pada wanita dengan indeks masa tubuh kurang dari 23.8 dan indeks masa tubuh 23.8-27.2 memiliki odds-ratio( OR) yaitu 1.4, dan pada wanita dengan indeks masa tubuh lebih dari 27.2 memiliki oddsratio( OR) yaitu 1.6. ${ }^{5}$ 


\section{Faktor Menopause dan Ginekologi}

Swift dkk, pada tahun 2001 dalam studinya menyebutkan bahwa pada wanita postmenopause yang tidak menjalani terapi pergantian hormon memiliki risiko lebih besar mengalami prolaps organ panggul dibandingkan dengan wanita pre-menopause dan wanita post-menopause yang menjalani terapi pergantian hormon. ${ }^{5}$

\section{Gaya Hidup}

Penyakit penyakit paru obstruktif kronik (PPOK) merupakan predisposisi untuk wanita mengalami prolaps organ panggul (POP). Namun, efek merokok atau asap rokok terhadap POP masih kontroversial. Selain itu, olahraga intensitas berat dan kerja fisik yang berat juga dapat menimbulkan kelainan dasar panggul. ${ }^{5}$

\section{Genetik dan Kolagen}

Dalam penelitiannya, Finnish menyebutkan bahwa insidensi prolaps genital berkontribusi sebanyak $30 \%$ untuk diturunkan dalam keluarga. Risiko terjadinya POP pada wanita dengan ibu atau saudara perempuan dengan POP, akan lebih tinggi dibandingkan degan wanita yang tidak memiliki riwayat POP dalam keluarga. ${ }^{5}$

Sindrom Ehlers-Danlos adalah kelainan jaringan ikat yang melibatkan kerusakan atau kecacatan dari gen kolagen. Wanita dengan sindrom ini memiliki risiko terjadinya POP lebih tinggi. ${ }^{5}$

\section{Gejala Klinik}

Gejala berbeda bersifat individual. Kadangkadang penderita dengan prolaps yang cukup berat tidak mempunyai keluhan apapun, sebaliknya penderita yang lain dengan prolaps ringan mempunyai banyak keluhan., 12,21 Keluhan yang sering dijumpai:
1. Perasaan adanya benda yang menonjol atau mengganjal di genitalia eksterna $(100 \%)$

2. Rasa sakit/nyeri di pinggang, biasanya bila penderita berbaring akan berkurang atau menghilang (13\%).

3. Sistokel dapat memberikan gejalagejala:

a. Sering berkemih dan sedikitsedikit (39\%)

b. Perasaan seperti kandung kemih tidak dapat dikosongkan seluruhnya (39\%)

c. Tidak dapat menahan kencing jika batuk, mengejan. Kadang-kadang dapat terjadi retensio urin pada sistokel yang besar.

4. Rektokel dapat memberi gangguan pada defekasi (39\%):

a. Konstipasi karena feses berkumpul dalam rongga rektokel

b. Baru dapat defekasi setelah diadakan penekanan pada rektokel dari vagina.

5. Enterokel dapat menyebabkan perasaan berat di rongga panggul dan perasaan penuh di vagina

6. Kesukaran untuk berjalan (45\%)

7. Kesulitan coitus (39\%)

\section{Pemeriksaan Fisik}

Saat pemeriksaan fisik prolaps organ panggul (POP), pasien harus dalam posisi litotomi. ${ }^{5}$ Pemeriksaan fisik difokuskan pada pemeriksaan panggul, dimulai dengan inspeksi pada vulva dan vagina untuk mengidentifikasi adanya erosi, ulserasi, atau lesi lain. ${ }^{21}$

Penggunaan spekulum Graves atau RetraktorBadendapatmembantumengevaluasi kompartemen apikal vagina. Kompartemen anterior dan posterior paling baik diperiksa dengan menggunakan spekulum univalve atau Sims. ${ }^{6}$ Pemeriksaan rektovaginal dapat membedakan prolaps vagina posterior, prolaps apikal tinggi (kemungkinan enterocele) atau 
kombinasi dari keduanya. ${ }^{22}$ Selama evaluasi setiap kompartemen, pasien didorong untuk melakukan Valsava sehingga prolapse dapat ditentukan telah sejauh mana. Jika temuan ditentukan dengan Valsalva tidak sesuai dengan deskripsi pasien tentang gejalanya, sebaiknya lakukan pemeriksaan sambil berdiri dengan kandung kemih kosong.,

\section{Diagnosis}

Diagnosis dibuat atas dasar anamnesis tentang gejala-gejala, kehamilan, fisik dan ginekologi. Sistokel dijumpai di dinding vagina depan benjolan kistik lembek dan tidak nyeri tekan. Benjolan bertambah besar jika penderita meneran. Jika kateter logam dimasukkan ke dalam kandung kemih dan kateter ini diarahkan ke dalam sistokel, dapat diraba kateter tersebut dekat sekali pada dinding vagina. ${ }^{10,12}$ Rektokel yaitu menonjolnya rektum ke lumen vagina sepertiga bagian bawah. Penonjolan berbentuk lonjong, dari proksimal ke distal, kistik dan tidak nyeri. Untuk memastikan diagnosis, jari dimasukkan ke dalam rektum, dan selanjutnya dapat diraba dinding rektokel yang menonjol ke lumen vagina. Enterokel menonjol ke lumen vagina lebih atas dari rektokel. Pada pemeriksaan rektal dinding rektum lurus, ada benjolan ke vagina terdapat diatas rektum. ${ }^{10,12}$ Sistem klasifikasi untuk menilai keparahan dari prolaps organ panggul yaitu Baden-Walker dan sistem POP-Q (Pelvic Organ Prolapse Quantitation System). ${ }^{5}$ Namun, untuk keperluan praktik klinis dan penelitian, sistem POP-Q lebih dipilih dibandingkan sistem Baden-Waker. ${ }^{14}$

Derajat sistem POP-Q didasarkan pada penurunan maksimal dari prolaps relatif terhadap himen pada satu atau lebih kompartemen. ${ }^{14}$ Klasifikasi system POP-Q menggunakan enam titik di sepanjang vagina (dua titik di anterior, tengah, dan kompartemen posterior) diukur dalam satuan sentimeter. Posisi anatomi dari enam titik yang ditentukan harus diukur dalam sentimeter proksimal himen(nilai negatif) atau distal ke himen (nilai positif), dengan himen sebagai titik nol nya. Tiga pengukuran lain dalam pemeriksaan POP-Q yaitu hiatus genital, badan perineum, dan total panjang vagina. $^{6}$

Gambar 6. Diagram terminologi untuk klasifikasi prolaps organ panggul wanita (POP-Q) $)^{6,23}$ 
Tabel 1 Jarak yang Mungkin dari Pengukuran Pemeriksaan Kuantitatif Prolaps Organ Panggul Spesifik-Lokasi ${ }^{5,6,23}$

\begin{tabular}{|c|c|c|}
\hline Titik & Deskripsi & Jarak \\
\hline Aa & $\begin{array}{l}\text { Titik yang berada pada dinding anterior, normalnya vagina } 3 \mathrm{~cm} \\
\text { proximal ke himen }\end{array}$ & dari $-3 \mathrm{~cm}$ hingga $+3 \mathrm{~cm}$ \\
\hline $\mathrm{Ba}$ & Titik yang terjauh yang mewakili fasia rektovagina & dari $-3 \mathrm{~cm}$ hingga $+\mathrm{TVL}$ \\
\hline $\mathrm{C}$ & Ujung paling distal dari cervix atau bekas luka vaginal cuff & $\pm \mathrm{TVL}$ \\
\hline $\mathrm{D}$ & Fornix posterior ( tidak ada jika post histerektomi) & $\pm \mathrm{TVL}$ or omitted \\
\hline Ap & $\begin{array}{l}\text { Titik yang berada pada dinding posterior, normalnya vagina } 3 \\
\mathrm{~cm} \text { distal ke himen }\end{array}$ & dari $-3 \mathrm{~cm}$ hingga $+3 \mathrm{~cm}$ \\
\hline $\mathrm{Bp}$ & Titik yang terjauh yang mewakili fasia rektovagina & dari $-3 \mathrm{~cm}$ hingga $+\mathrm{TVL}$ \\
\hline
\end{tabular}

Genital hiatus (gh) - mengukuran dari bagian tengah uretra eksternal ke garis tengah posterior himen

Perineal body $(\mathrm{pb})$ - diukur dari margin posterior gh ke bagian tengah mulut anal

Total vaginal length (tvl) - kedalaman vagina saat poin D atau C menurun dari posisi normal

\section{Kriteria Stadium POP-Q}

\section{Tabel 2 Kriteria stadium POP-Q5}

\begin{tabular}{|c|c|}
\hline Stadium 0 & $\begin{array}{l}\text { Tidak ada prolaps. Titik Aa, Ap, Ba, Bp berada di }-3 \mathrm{~cm} \text { dan titik } \mathrm{C} \text { atau D berada } \\
\text { di antara tvl hingga (tvl-2)cm }\end{array}$ \\
\hline Stadium I & $\begin{array}{l}\text { Tidak termasuk kriteria stadium } 0 \text { tapi ujung distal bagian yang prolaps }>1 \mathrm{~cm} \text { dia- } \\
\text { tas bidang hymen (nilai perhitungan }>-1 \mathrm{~cm} \text { ) }\end{array}$ \\
\hline Stadium II & $\begin{array}{l}\text { Ujung distal bagian yang prolaps berada } 1 \mathrm{~cm} \text { dibawah dan } 1 \mathrm{~cm} \text { diatas bidang } \\
\text { cincin hymen (nilai perhitungan } \geq-1 \mathrm{~cm} \text { tapi } \leq+1 \mathrm{~cm} \text { ) }\end{array}$ \\
\hline Stadium III & $\begin{array}{l}\text { Ujung distal bagian yang prolaps }>1 \mathrm{~cm} \text { dibawah bidang hymen, namun protusi } \\
\text { tidak lebih dari (tvl-2)cm (nilai perhitungan }>+1 \mathrm{~cm} \text { tapi }<+(\text { tvl-2) } \mathrm{cm})^{11}\end{array}$ \\
\hline Stadium IV & $\begin{array}{l}\text { Merupakan eversi komplit dari total panjang traktus genitalia bawah. Ujung distal } \\
\text { bagian yang prolaps berprotusi minimal (tvl-2)cm (nilai perhitungan } \geq+(\text { tvl-2) } \\
\mathrm{cm})\end{array}$ \\
\hline
\end{tabular}

Diagram Terminologi untuk Klasifikasi Prolaps Organ Panggul Wanita (POP-Q)

\section{Komplikasi}

Pada sistokel berat kadang-kadang miksi terhalang, sehingga kandung kemih tidak dapat dikosongkan seluruhnya, dapat pula mengubah bentuk sudut antara kandung kemih dan urethra yang dapat menimbulkan stress inkontinensia. ${ }^{10,12}$

Hemoroid dapat terjadi karena feses yang terkumpul dalam rektokel memudahkan adanya konstipasi. Inkarserasi usus halus. Usus halus yang masuk ke dalam enterokel dapat terjepit dengan kemungkinan tidak dapat direposisi lagi. Dalam hal ini perlu dilakukan laparatomi untuk membebaskan usus yang terjepit tersebut. ${ }^{12}$

\section{Penatalaksanaan}

Tidak semua prolapsus alat genitalia membutuhkan terapi, karena banyak penderita tidak mempunyai keluhan, terutama stadium I dan kadang-kadang stadium II.

Pada mereka yang mempunyai keluhan tentu perlu penanganan dengan tepat agar penderita merasa lebih baik. Perlu disadari oleh para dokter, bahwa prolapsus alat genitalia merupakan suatu kelainan, bukan 
penyakit sehingga tidak mengancam jiwa penderita. Tindakan dapat berupa konservatif dan operatif. Tindakan konservatif, berupa pencegahan dan penggunaan alat penyokong (alat bantu). ${ }^{3}$

Pencegahan:

- Mengurangi hal-hal yang dapat meningkatkan tekanan intraabdominal meningkat, seperti batuk yang kronis, mengangkat benda-benda berat.

- Melakukan latihan otot-otot dasar panggul

- Menghindari persalinan lama

- Persalinan ditolong dengan baik

- Mengurangi jumlah anak (keluarga berencana)

\section{Observasi}

Observasi dilakukan pada pasien yang asimtomatik, sedikit gejala, atau tidak merasa terganggu dengan penyakit yang dialaminya. Observasi merupakan pilihan terapi yang tepat pada pasien dengan prolaps ringan yang belum melewati himen. Observasi dilakukan secara berkala untuk memantau perkembangan dari penyakit pasien. ${ }^{21}$

\section{Terapi Konservatif}

Terapi konservatif merujuk pada terapi nonbedah yang dipertimbangkan untuk wanita dengan prolaps ringan hingga sedang, wanita yang masih ingin melahirkan anak, dan wanita yang tidak menginginkan intervensi bedah. Tujuan dari terapi konservatif ini adalah sebagai berikut: 6

1. Mencegah prolaps semakin memburuk

2. Mengurangi keparahan gejala

3. Meningkatkan kekuatan, daya tahan, dan dukungan otot dasar panggul

4. Menghindari atau menunda intervensi bedah

\section{Modifikasi Gaya Hidup}

Perubahan gaya hidup yang dapat diberikan pada pasien prolaps organ panggul yaitu menurunkan berat badan, menghindari aktivitas fisik yang dapat meningkatkan tekanan intra-abdomen (contohnya angkat beban, batuk), dan berhenti merokok. Perubahan gaya hidup dinilai mampu mengurangi gejala dan menghindari eksaserbasi dari POP. ${ }^{6}$

\section{Penggunaan Alat}

Penggunaan alat mekanis seperti pesarium biasanya dipertimbangkan untuk wanita yang tidak dapat menjalani operasi karena alasan medis, ingin menghindari operasi, atau memiliki stadium prolaps yang lebih parah yang membuat pendekatan non-bedah lainnya tidak dapat dilakukan. ${ }^{6}$

\section{Fisioterapi}

Fisioterapi pada pasien POP bertujuan untuk mengurangi gejala POP dan meningkatkan fungsi dan kekuatan otot dasar panggul. Fisioterapi yang diberikan contohnya adalah pelatihan otot dasar panggul (PFMT). ${ }^{6,24}$

\section{Terapi Hormon Topikal}

Hormon estrogen memiliki peran penting dalam menyokong pelvis dengan mengontrol sintesis dan pemecahan kolagen. Turunnya kadar hormon estrogen dalam tubuh setelah menopause menjadi salah satu etiologi sekaligus faktor risiko terjadinya POP. Estrogen topikal menjadi fokus perhatian untuk pengobatan POP dalam beberapa tahun terakhir karena rendahnya efek samping yang diberikan dibandingkan terapi hormone secara sistemik. Bentuk estrogen topikal yang diberikan dapat berupa krim secara terpisah, atau dapat digabungkan bersama pessarium.

Pada wanita post-menopause, krim 
estrogen dosis rendah dapat menjadi pengobatan tambahan yang penting dalam meningkatkan tonus jaringan dan mengembalikan perubahan atrofi pada mukosa vagina. ${ }^{4,25}$

\section{Terapi Bedah Konservatif}

Terapi bedah konservatif untuk POP pertama kali diperkenalkan oleh Archibald Donald dan William Fothergill. Terapi tersebut kemudian diberi nama 'Operasi Manchester' atau 'Operasi Fothergill'.

Operasi Manchester merupakan suatu prosedur yang melibatkan eksisi dari serviks dan penjahitan mulut serviks ke ligamen kardinal. Operasi Manchester dinilai efektif dalam memperbaiki prolaps uterus yang disebabkan oleh elongasi serviks, namun tidak efektif dalam memperbaiki prolaps karena turunnya badan uterus dibandingkan histerektomi. Ginekologis di India banyak mengembangkan bedah konservatif berupa operasi selempang (sling operation), yaitu mengganti fasia asal organ dengan fasia prostetik yang terbuat dari bahan seperti mersilene. Operasi selempang ini dinilai memiliki efek samping lebih sedikit dan memberikan sokongan lebih tahan lama. ${ }^{26,27}$

\section{Terapi Operasi}

Tujuan utama pembedahan adalah untuk meredakan gejala yang mungkin disebabkan oleh prolaps untuk memulihkan anatomi vagina sehingga fungsi seksual dapat dipertahankan atau membaik tanpa efek samping atau komplikasi yang signifikan. ${ }^{6}$

Pada prolaps vaginal tumpul, dapat dibantu dengan pesarium, bila tidak bisa baru dilakukan operasi. Pada wanita yang mengalami prolaps vaginal tumpul dapat dikoreksi dengan suspensi apeks vagina ke titik-titik tetapdidalampanggul seperti sakrum (abdominal sacral colpopexy), ligamen uterosakral (high uterosacral ligament suspension), atau ligamen sakrospinous (sacrospinous ligament fixation). Tingkat keberhasilan tergantung pada keahlian ahli bedah, derajat relaksasi panggul, dan usia, berat badan, dan gaya hidup pasien. ${ }^{4}$

Pada pasien prolaps vaginal tumpul atau vaginal vault prolapse dapat diberikan prosedur operatif yaitu: ${ }^{4}$

1. Kolpopeksi abdominosakral

Peksi adalah istilah dalam ilmu bedah yang berarti fiksasi. ${ }^{28}$ Kolpopeksi abdominosakraladalahpendekatanstandar untuk prosedur suspensi vagina apikal transabdominal. ${ }^{6}$ Bentuk prosedurnya menggunakan jaring prostetik (mesh) untuk melekatkan apeks vagina ke sakrum via pendekatan laparoskopi atau robotik. ${ }^{4}$ Keuntungan kolpopeksi abdominosakral adalah jaringan parut dan denervasi yang lebih sedikit dibandingkan operasi dengan pendekatan transvaginal. Kolpopeksi abdominosakral memiliki waktu operasi dan masa penyembuhan pasien lebih lama dibandingkan dengan fiksasi ligament sacrospinous. Komplikasi yang diakibatkan oleh kolpopeksi abdominosakral yaitu erosi graft, perdarahan intraoperatif yang signifikan (terutama di daerah pre-sacral), ileus pasca operasi, obstruksi usus halus, adesi intra-abdominal yang mengakibatkan nyeri dan disfungsi usus dan komplikasi luka, seperti seroma dan infeksi. ${ }^{4,6,22}$

2. Suspensi ligament uterosacral

Suspensi adalah pelekatan organ atau bagian tubuh lainnya pada sebuah struktur penyangga seperti uterus atau kandung kemih pada perbaikan hernia atau prolapse. ${ }^{28}$ Bentuk prosedur suspensi ligament uterosacral yaitu dengan menahan ligamen uterosakral melalui pendekatan per-vagina. ${ }^{4,6}$

3. Fiksasi ligament sacrospinous

Fiksasi dalam bedah adalah proses 
menguatkan atau menjahit atau mengencangkan dalam posisi tetap. ${ }^{28}$ Fiksasi ligament sacrospinous adalah fiksasi apeks vagina ke ligamentum sakrospinous, komponen tendineus dari otot coccygeus. Akses ekstraperitoneal melalui ruang rectovaginal dengan penetrasi pararektal (fasia Denonvillier) di tingkat tulang belakang iskia untuk mengekspos otot dan ligamen. Akses dapat juga melalui lateral anterior, bagian apikal posterior ligamentum uterosakral, dan pendekatan laparoskopi. ${ }^{6}$

4. Kolpokleisis

Pasien dengan kontraindikasi dilakukannya operasi, tidak mempunyai suami lagi atau tidak ada aktifitas seksual dapat ditawarkan kolpokleisis. Ini adalah prosedur obliteratif vagina yang menutup saluran vagina sebagai cara untuk mengobati prolaps organ panggul yang bergejala. Prosedur ini kurang invasif dengan waktu operasi yang lebih singkat, komplikasi dan kekambuhan yang lebih sedikit, dan tingkat kepuasan pasien yang tinggi. ${ }^{4}$

\section{Kesimpulan}

Prolaps alat genitalia atau prolapse organ panggul (POP) terdapat pada wanita yang sering melahirkan dan $40 \%$ dari mereka membutuhkan tindakan pengobatan. Walaupun tidak mengancam nyawa, akan tetapi prolapsus alat genitalia dapat menurunkan kualitas hidup wanita.

Persalinan pervaginam merupakan penyebab paling signifikan terhadap terjadinya prolaps organ panggul dikarenakan teregangnya otot levator ani dan saraf pudendal. Faktor risiko yang berkontribusi dalam menyebabkan prolapse organ panggul diantaranya usia, ras, paritas, obesitas, faktor menopause dan ginekologi, gaya hidup, genetik dan kolagen. Untuk keperluan praktik klinis dan penelitian, sistem POP-Q lebih dipilih dibandingkan sistem Baden-Waker. Kriteria stadium menurut sistem POP-Q terdiri dari stadium I,II,III,IV. Tatalaksana prolapse organ panggul berupa observasi, konservatif dengan modifikasi gaya hidup, penggunaan alat, fisioterapi, terapi hormon topikal, bedah konservatif, dan operasi.

\section{Daftar Pustaka}

1. Rizkar M. Prolap Uteri. In: Junizaf and Santoso BI (eds) Buku Ajar Uroginekologi Indonesia. Jakarta: Himpunan Uroginekologi Indonesia Bagian Obstetri dan Ginekologi FKUI, 2011, pp.29-37.

2. Hacker NF, Gambone JC and Hobel CJ. Hacker \& Moore's Essentials of Obstetrics and Gynecology. Elsevier Health Sciences, 2015.

3. Junizaf. Buku Ajar Uroginekologi Indonesia. Jakarta: Himpunan Uroginekologi Indonesia Bagian Obstetri Ginekologi FKUI, 2011.

4. Callahan TL and Caughey AB. Blueprints Obstetrics and Gynecology. 7th ed.: Lippincott Williams \& Wilkins, 2017, p.1312.

5. Raz S and Rodriguez LV. Female Urology. 3 ed.: Elsevier Health Sciences, 2008, p.1056.

6. Berek JS. Berek \& Novak's Gynecology. 15 ed.: Lippincott: Williams \& Wilkins, 2012.

7. Pangastuti N, S. DCR, Santoso BI, et al. Gambaran Faktor Risiko Prolaps Organ Panggul Pasca Persalinan Vaginal di Daerah Istimewa Yogyakarta. Majalah Kedokteran Bandung 2018; 50. DOI: 10.15395/mkb.v50n2.1321.

8. Leveno KJ, Spong CY, Dashe JS, et al. Williams Obstetrics. 25 ed.: McGrawHill Education, 2018, p.1344.

9. Cardozo L. Prolapse. Urogynecology the king's approach. Churchill Livingstone, 1977, pp.321-346. 
10. Wall L. Incontinence, Prolapse, and Disorder of the Pelvic Floor. In: JS. B, EY. A and PA. H (eds) Novak's Gynecology. 2 ed. Baltimore: Williams \& Wilkins, 1996, pp.619-663.

11. Rock J and Thompson J. Surgical Correction of Defects in Pelvic Support. In: JA R and JD T (eds) Te linde's Operative Gynecology. 8 ed. New York: Lippincott-Raven, 1977, pp.951-1077.

12. Junizaf. Kelainan letak alat-alat genital. In: H W (ed) Ilmu Kandungan. Jakarta: Yayasan Bina Pustaka, 1997, pp.420-446.

13. Petros PEP. The Female Pelvic Floor. 2 ed.: Springer, 2007, p.279.

14. Hamamah J and Pangastuti N. Karakteristik Pasien Prolaps Uteri di RSUP Dr. Sardjito Yogyakarta Tahun 2013. Jurnal Kesehatan Reproduksi 2017; 4: $17-22$.

15. Uzoma A and Farag KA. Vaginal Vault Prolapse. Obstetrics and Gynecology International 2009; 2009: 9. DOI: $10.1155 / 2009 / 275621$.

16. Sayko SK, Kurniawati EM and Lestari P. Age as the Risk Factor that Affected the Increased Degree of Uterine Prolapse. Biomolecular and Health Science Journal 2018

17. Kim S, Harvey M-A and Johnston S. A Review of the Epidemiology and Pathophysiology of Pelvic Floor Dysfunction: Do Racial Differences Matter? Journal of Obstetrics and Gynaecology Canada 2005; 27.

18. Renata I, Rizkar M, R. L, et al. Perbandingan Kerapatan Kolagen Ligamentum Sakrouterina pada Pasien dengan dan tanpa Prolaps Uteri. Majalah Kedokteran Bandung 2015; 47. DOI: 10.15395/mkb.v47n4.624.

19. Bent AE, Ostergard DR, Cundiff GW, et al. Ostergard's Urogynecology \& Pelvic Floor Dysfunction. 5 ed.: Lippincott: Williams \& Wilkins, 2003, p.587.

20. Barrington $\mathrm{J}$ and Edwards G.
Posthysterectomy Vault Prolapse. International Urogynecology Journal 2000: 241-245.

21. Timmons M, Addison W, Addison S, et al. Abdominal Sacral Colpoxy in 163 Women with Posthysterectomy vaginal vault prolapse and enterocele. The Journal Reproductive Medicine 1992: 323-337.

22. Pratiwi KYM and Putra IGM. Prolaps Organ Panggul. Open Journal System Universitas Udayana.

23. Bump R, Mattiason A and Brubaker L. The Standardization of terminology of female pelvic organ prolapse and pelvic floor dysfunction. American Journal of Obstetrics \& Gynecology 1996: 10-17.

24. Haylen BT, Mather CF, Barber MD, et al. An International Urogynecological Association (IUGA) / International Continence Society (ICS) joint report on the terminology for female pelvic organ prolapse (POP). International Urogynecology Journal 2016; 27. DOI: 10.1002/nau.22922.

25. Weber MA, Kleijn MH, Langendam $\mathrm{M}$, et al. Local Oestrogen for Pelvic Floor Disorders: A Systematic Review. PLoS ONE 2015. DOI: 10.1371/journal. pone. 0136265 . 